Vol. 3, No. 2, 2017

\author{
Lubomyr Borushchak ${ }^{1}$, Stepan Borushchak ${ }^{2}$, Oleh Onysko \\ ${ }^{1}$ Department of Computerized Machine-Building Manufacturing, Ivano-Frankivsk National Technical \\ University of Oil and Gas, 15, Karpatska Str., Ivano-Frankivsk, Ukraine, E-mail: kmv@nung.edu.ua \\ ${ }^{2}$ Ivano-Frankivsk National Technical University of Oil and Gas, 15, Karpatska Str., Ivano-Frankivsk, Ukraine, \\ ${ }^{3}$ Department of Computerized Machine-Building Manufacturing, Ivano-Frankivsk National Technical \\ University of Oil and Gas, 15, Karpatska Str., Ivano-Frankivsk, Ukraine, E-mail: onysko.oleg@gmail.com

\section{INFLUENCE OF THE TECHNOLOGICAL GAP VALUE OF THE TOOL-JOINT TAPERED THREAD ON THE DRILLING MUD FLOW RATE IN ITS SCREW COUPLING} E-mail: kmv@nung.edu.ua

Received: December 12, 2017 / Revised: December 25, 2017 / Accepted: December 26, 2017

(C) Borushchak L., Borushchak S., Onysko O., 2017

\begin{abstract}
Tightness is one of the parameters of the quality of pipe drill string. Consequently, the reduction of hydraulic costs and wear of the tool-joint tapered thread of the drill string can be achieved by changing the cutting part of the cut tools. It is precisely because of the reduction of the tightness we have bigger expense of hydraulic energy on the one hand and the wear on the surface of the thread is accelerated, since the drilling fluid together with the abrasive, moves along the screw threaded channel at a high speed (over $50 \mathrm{~m} / \mathrm{s}$ ) on the other side. To date, the tightness of tool-joint tapered thread provided in two ways. The second is the filling of the spiral channel, which is formed due to the standard gap between the box and the pin by a special lubricating and sealing filler. Typically, such fillers in the presence of significant pressure and untightness when contacting the ends of the box and pin are displaced from the channel. The authors of the article propose to reduce the cross-sectional area of the specified gap to achieve a sharp decrease in the speed of the drilling mud in the channel formed by the gap. As a result of the virtual experiment, actual data were obtained regarding the speed of the drilling mud, which became 40-50 times smaller in the case of a decrease in the height of the channel by 4 times and its width by 1.6 times. In the article it is shown that the existing sizes and tolerances for the gaps in the standard are of an optional nature and are presented for the design of a cutting tool for cutting. Consequently, the reduction of hydraulic costs and wear of the tool-joint tapered thread of the drill string can be achieved by changing the cutting part of the cut tools.
\end{abstract}

Keywords: pipe drill string, tool-joint tapered thread, drilling mud, tolerances for the gaps, cutting part of the cut tools, box and pin.

\title{
Introduction
}

The tool-joint tapered thread quality is determined by three basic parameters: impermeability, strength, screw driving. To ensure the impermeability of the drill pipe string tool-joint the following two techniques are used: design and technological.

The technological techniques are reduced to filling the screw groove of the tool-joint with different fillers, which should simultaneously fulfil the role of lubrication in the process of the drilling-pipe screwing and the role of the closure, which would not be able to pass the drilling mud through the screw channel formed between box and a pin. This occurs extremely rare, since large pressures, which accompany both rotor and turbine drilling, are gradually replacing these fillers, especially when the ends of the nipple and the box cease to fit tightly to each other over time, and consequently the probability of depressurization increases. 
The design techniques are reduced to the improvement of the nipple and box ends. The phenomenon of depressurization is especially common in the process of sloping drilling and horizontal drilling. This is obviously due to the effect of lateral bending loads on the drill string and its joints. Therefore, the issue of tightness of the drill string joints is very relevant and requires comprehensive research.

\section{Review of Modern Information Sources on the Subject of the Paper}

The authors [1] prove that the depressurization of the tapered tool-joint in the inclined drilling is due to the opening of the joint between the box end and the nipple end received as a result of reaching the maximum permissible radius of the curvature of the axis of the drill pipe string.

In the tool-joint tapered thread of the drill pipe string there is clearance between the box and the pin [2]. In Fig. 1 this gap is schematically shown in black. The height of the gap is about $0.5 \mathrm{~mm}$.

Therefore, in the opinion of the author [3], for large values of the pressure difference between the inner cavity of the drill pipe and the annular space, the probability of not just leakage, but also the erosion of the spiral channel in the tool-joint is quite large even in the presence of a sealing-filler. That is, the author [3] believes that only ensuring the proper contact pressure between the coupling and the nipple will provide leak proofness.

At the same time, the work [4] indicated that after the lock connection tightening, the contact stresses along the width of the stop joint are distributed unevenly.

In work [5] the influence of the nonperpendicularity of the end faces of the coupling and the nipple as a result of their operation was investigated.

The research of the screw channel itself, which is formed due to the gap laid in standard [2], was carried out in works [6;7]. The author [6] points out that the increase of this gap due to wear is the cause of the loss of hydraulic energy of the drilling mud during the drilling process. The authors [7] present the virtual experiments results, which prove that the rate of flow of drilling mud through these gaps reaches $50 \mathrm{~m} / \mathrm{s}$ at a pressure of $10 \mathrm{MPa}$ and exceeds $110 \mathrm{~m} / \mathrm{s}$ at a pressure of $20 \mathrm{MPa}$. In this work, the experiment was carried out in the absence of an end seal between coupling and a nipple, which actually occurs as a consequence of a number of reasons, among which, as already mentioned above - the excess of the boundary value of the curvature of the axis of the drill pipe string.

Based on the described analysis of literary sources, we conclude that there is a need to investigate the speed of a drilling mud through a structural clearance, provided that it reduces its value at the stage of manufacturing the tool-joint tapered thread.

\section{Objectives and Problems of Research}

The purpose of the article consists in investigation of the influence of the structural gap of the pipe string tool-joint on the drilling mud flow rate in it.

The problems of research are as follows:

1. To analyse the possibilities of design and technological procedures aimed at reducing the size of the gap defined in the standard [2].

2. After reaching of the needed reducing of the gap area by using of SolidWorks and Flow Simulation software, to create a virtual 3D model of the screw channel, which is formed between the nipple and box of the tapered thread joint C-73 (according to the ARI 7 (US) joint $27 / 8$ Reg).

3. To compare the results of the drilling mud speed in the screw channel of the tool-joint at different values of it's cross-sectional area.

\section{Analysis of the possibilities of the gap size reducing}

Figure 1 shows a schematic drawing of a tool-joint tapered thread for drill string based on the standard [2]. In this document, a number of dimensions and tolerances are optional and are given for the cutter tool design.

The following designations are used: $P$ - pitch; $H$ - non-truncated thread height; $h_{1}-$ truncated thread height; $h$ - truncated work thread height; $a$ - width of flat; $r$ - root radius; $\alpha / 2$ - half profile 
angle. The black color shows the cross-section between the box and the pin. The values $a$ and $h$ are shown as reference sizes. Fig. 2 shows a larger scale gap between the box and the pin. It is separated by a dash between the arc of DFE and its chord DE. As shown in Fig. 2, section DE corresponds to the value of $a$-the width of flat. A it may be seen in Figs. 1-2, the height of the figure equals the difference $\left(h_{1}-h\right)$.

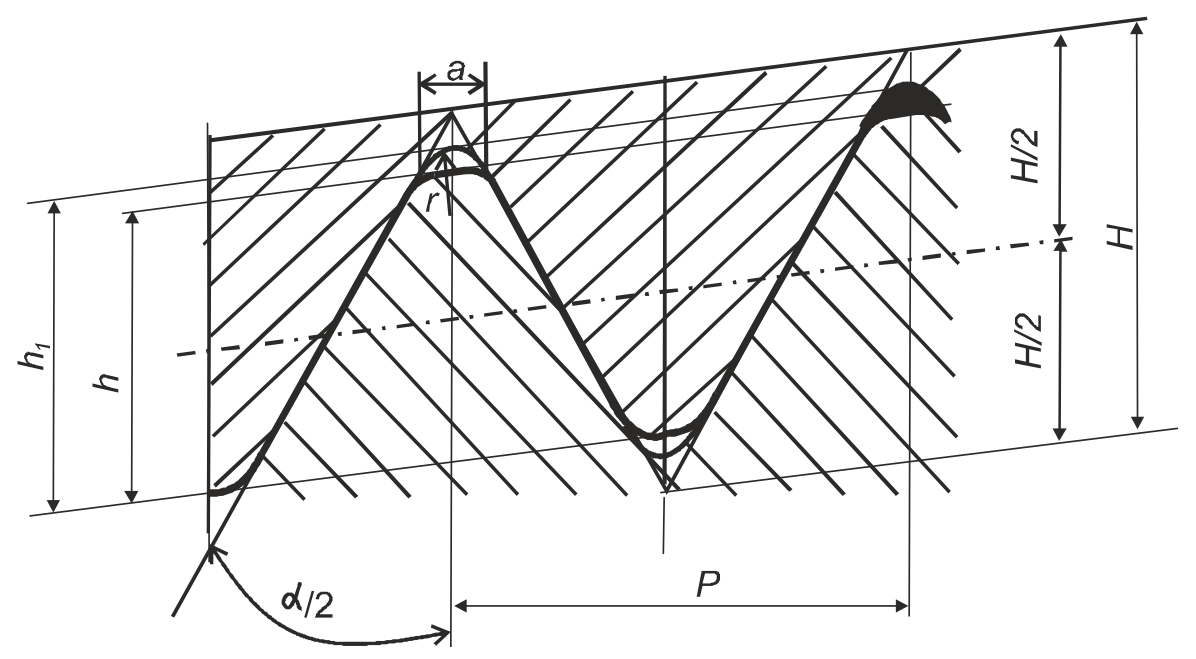

Fig. 1. Scheme of the tool-joint tapered thread for the drill pipe string

Since the value of $h$ and tolerance to it are not defined by standard [2] as obligatory, then let us introduce value $\delta_{\eta}$ that means the increase of the size of $h$. As a result of this increase, the floor area moves from the segment DE to the segment AC. Its length is marked as $a_{1}$ (Fig. 2).

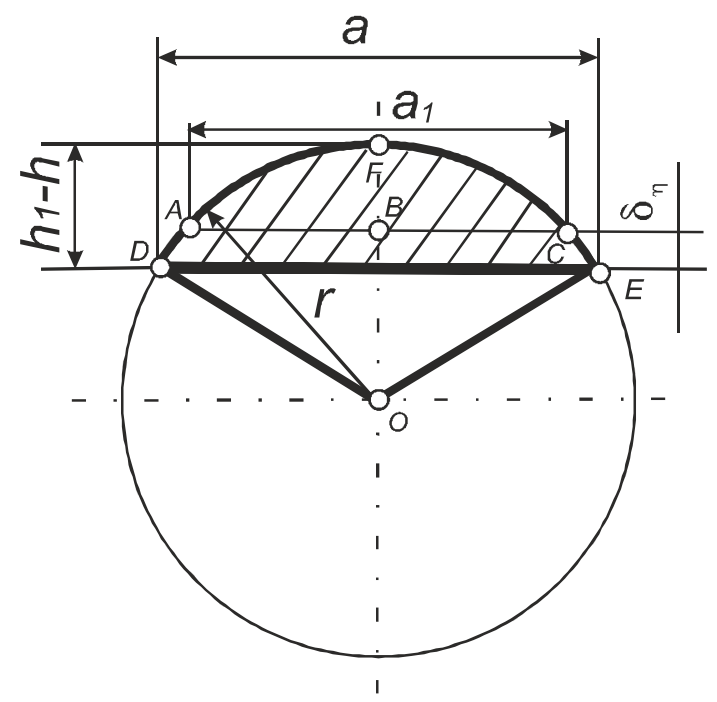

Fig. 2. Scheme of increasing of the tool-joint tapered thread gap

\section{Geometric calculation of the gap height}

Therefore, the newly created gap is located between arc AFC and its chord AC. For further experiment, we need to calculate the relationship between the value of the chord $\mathrm{AC}$ and the height $\mathrm{FB}$ of the result shape:

$$
|F B|=\left(h_{1}-h\right)-\delta_{\eta} .
$$


From the rectangular triangle $\mathrm{OAB}$ :

$$
r^{2}=|A B|^{2}+|B O|^{2}=\left(\frac{a_{1}}{2}\right)^{2}+\left(r-\left(h_{1}-h\right)+\delta_{\eta}\right)^{2} .
$$

We can solve Eq. 1 in order to define $\delta_{\eta}$ :

$$
\delta_{\eta}=\sqrt{r^{2}-\left(\frac{a_{1}}{2}\right)^{2}}-r+h_{1}-h .
$$

In order to facilitate the virtual experiment in SolidWorks software using Flow Simulation environment, we will apply some simplification of the shape presented in Fig. 2. The shape between the arc AFC and its chord AC is replaced by the AFC triangle (Fig. 3). This technique is correct, since the last point in the statement of the problem is to compare the speed of the drilling mud. This means that it is possible to select triangles with different values of the base $a_{1}$ and its height.

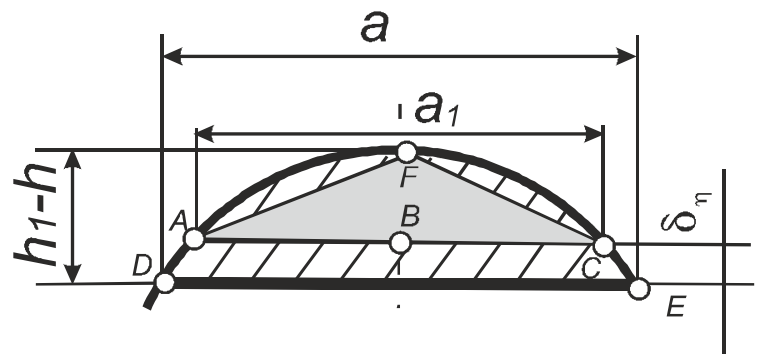

Fig. 3. Scheme of the gap shape for the virtual experiment in SolidWorks and Flow Simulation software

\section{Input data for research}

In order to conduct the research we chose tapered thread joint $\mathrm{C}-73$ as the dimension base. It is characterized by the following parameters [2]: taper 1:6; motion of the thread $6.35 \mathrm{~mm}$; height of the profile $2.64 \mathrm{~mm}$; profile angle $60^{\circ}$; the diameter of the end of the nipple is $60.38 \mathrm{~mm}$; the length of the joint itself is about $60 \mathrm{~mm}$; truncated thread height $3.095 \mathrm{~mm}$; root radius $0.965 \mathrm{~mm}$; width of flat $1.651 \mathrm{~mm}$.

The selected joint size is shorter than any other, which allow significant saving of computer resources and time of calculations during the simulation of the process of flow of the drilling fluid. Using the practical data of the drilling parameters, as well as the data of the analysis of works [6;7], we set values of the working pressure for the solution in the plane of the channel entrance $-10 \mathrm{MPa}$.

\section{Defining the new gap sizes}

The value $\mathrm{a}_{1}$ equals $1 \mathrm{~mm}$. After entrance parameters of tool-joint $\mathrm{C}-73$ to Eqs. $1-2$, we receive $\mathrm{FB}=0.134 \mathrm{~mm}$.

\section{Research results}

The research was carried out according to the algorithm presented in [7]. The rheological model was selected using the works [8; 9]. For this investigation, we offer to apply the rheological model of HerschelBalkley, analogically as in [7].

The research results are made in the form of a three-dimensional pressure and speed diagram in the channel with the analysis of numerical data of legends in the upper left corner. On all the diagrams, the direction of the jet is shown with the arrows.

The average results of the speed of the channel are from $1.12 \mathrm{~m} / \mathrm{s}$ to $1.48 \mathrm{~m} / \mathrm{s}$ (Fig. 4).

At the entrance section of the spiral gap channel, the results of the speed distribution are shown in Fig. 5 ( the speed varies from $0.93 \mathrm{~m} / \mathrm{s}$ to $1.362 \mathrm{~m} / \mathrm{s}$ ). 
The velocity in the middle of the channel is $1.362 \mathrm{~m} / \mathrm{s}$ (Fig. 6).

In the exit of the spiral gap channel, the speed is distributed from $0.558 \mathrm{~m} / \mathrm{s}$ to $1.362 \mathrm{~m} / \mathrm{s}$ (Fig. 7).

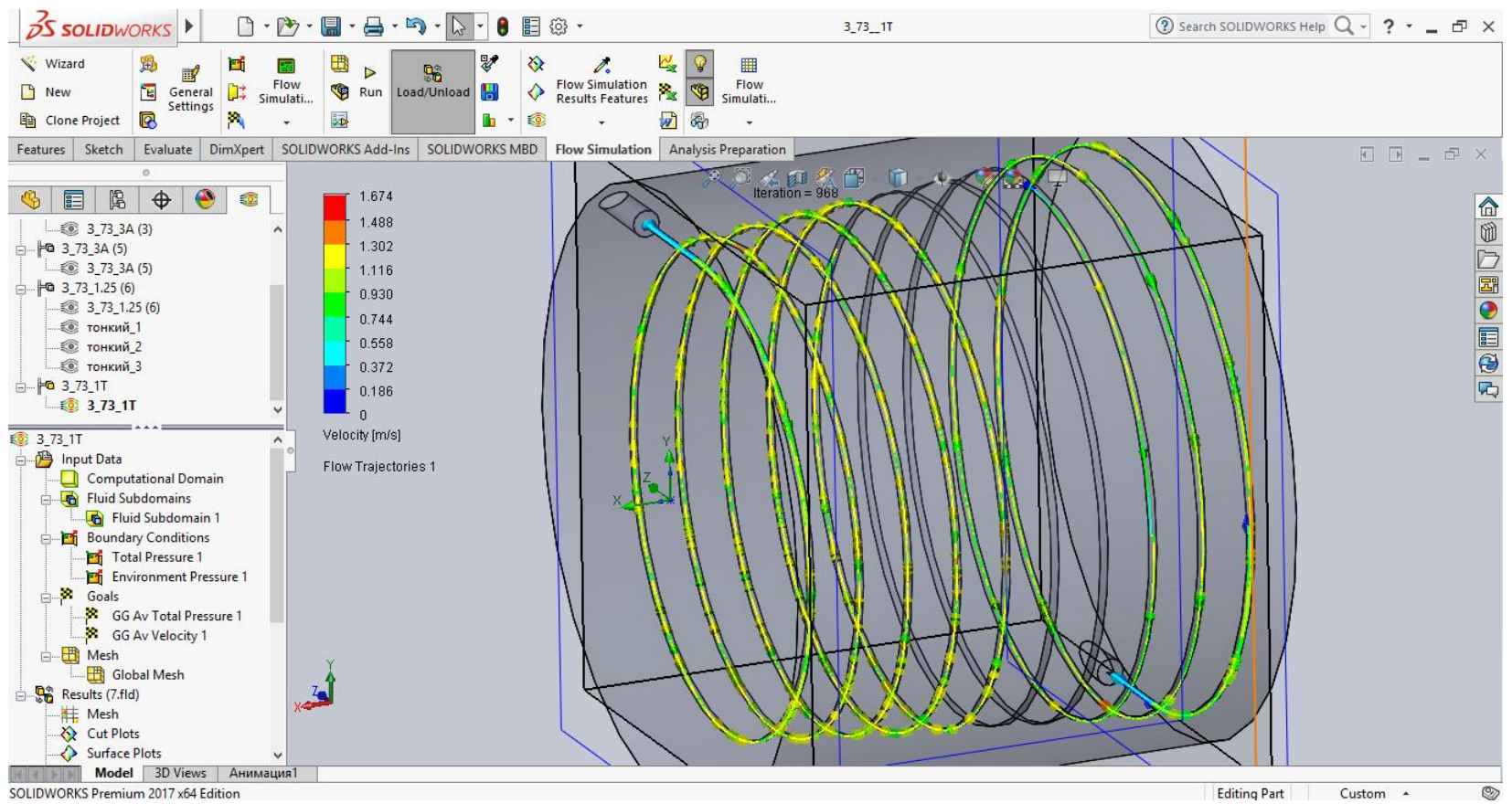

Fig. 4. Diagram of flow rates of drilling mud along the spiral gap channel

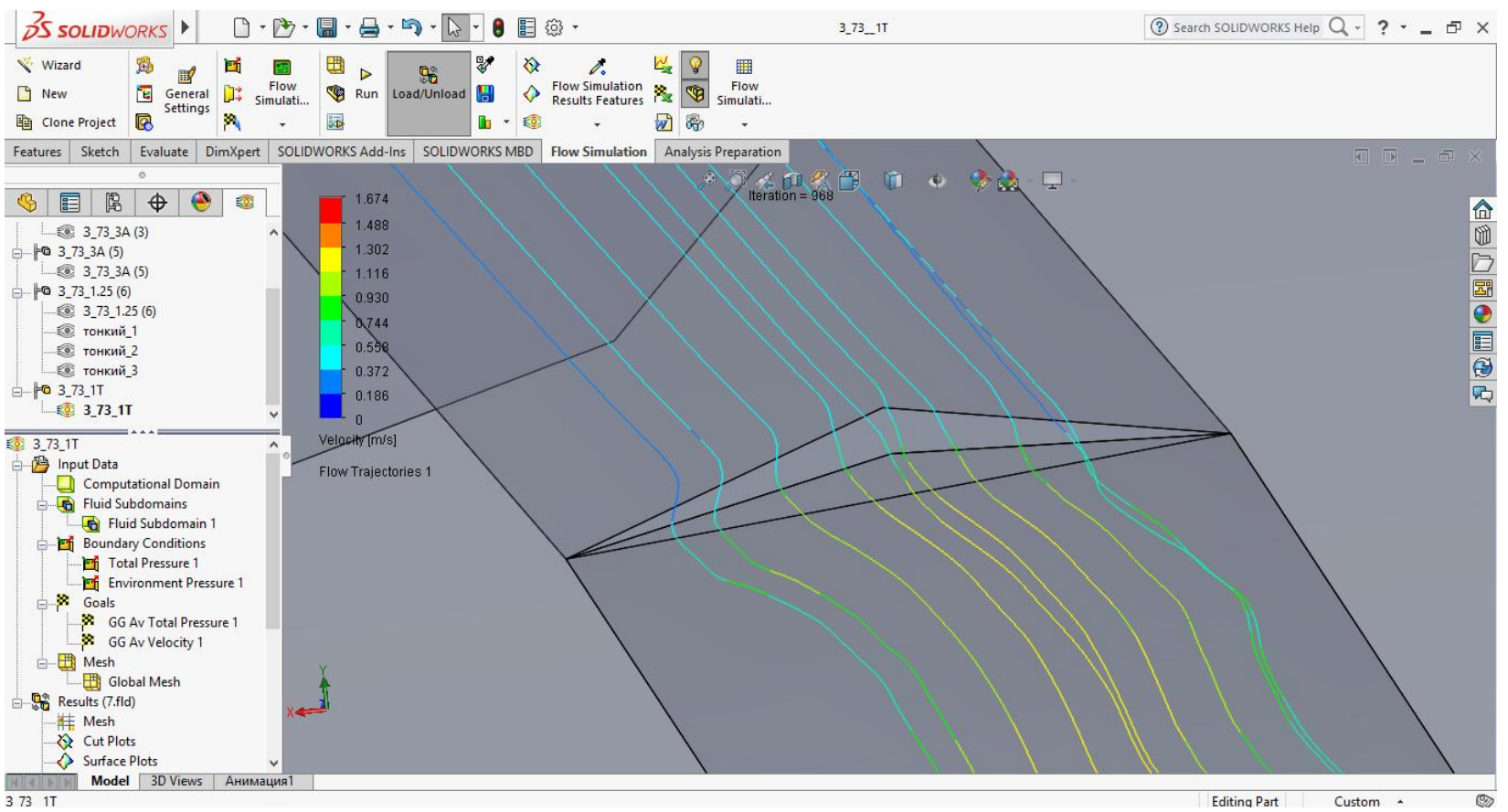

Fig. 5. Diagram of flow rates of drilling mud in the entrance of the spiral gap channel

The characterization of the rate distribution along the channel section at the input (Fig. 8) and the exit (Fig. 9) are the similar: from the minimum on the edges - to the maximum in the middle of the crosssection of the gap. The maximum speed at the middle of the entrance section is $1.4 \mathrm{~m} / \mathrm{s}$ (Fig. 8) that is slightly larger than the speed at the middle of the exit section $-1.1 \mathrm{~m} / \mathrm{s}$ (Fig. 9). 


\section{Speed comparison results}

The data with a standard gap and an input pressure of $10 \mathrm{MPa}$ indicate the flow rate of the drilling fluid in the screw channel between the pin and the box ranges from $30 \mathrm{~m} / \mathrm{s}$ to $55 \mathrm{~m} / \mathrm{s}$ [7].

At the same time, the range of velocity distribution for a slightly reduced section of the channel at $a_{1}=1 \mathrm{~mm}$ (Figs. 2-3) is varying from $0.558 \mathrm{~m} / \mathrm{s}$ to $1.48 \mathrm{~m} / \mathrm{s}$.

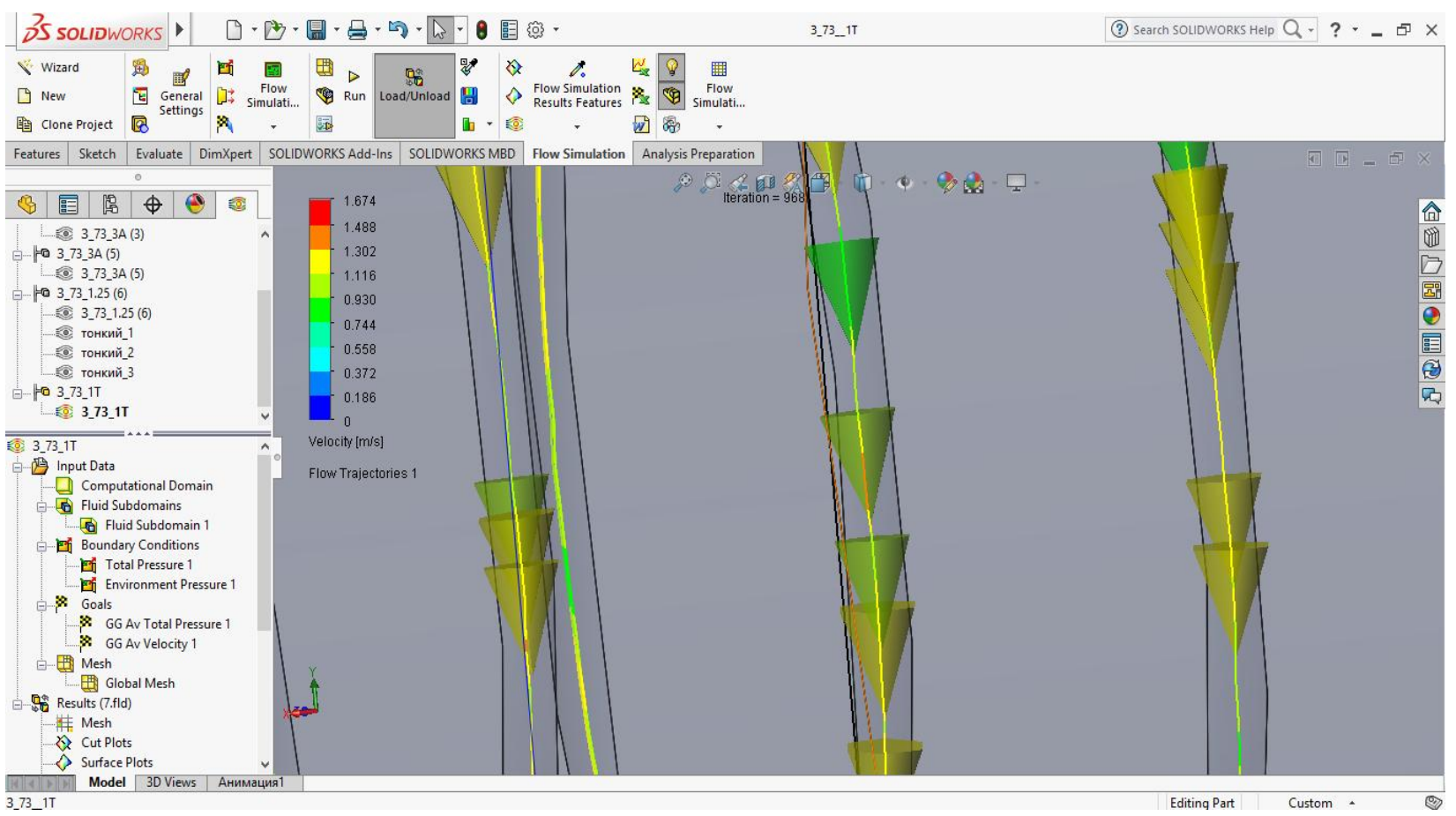

Fig. 6. Speed diagram in the middle part of the spiral gap channel

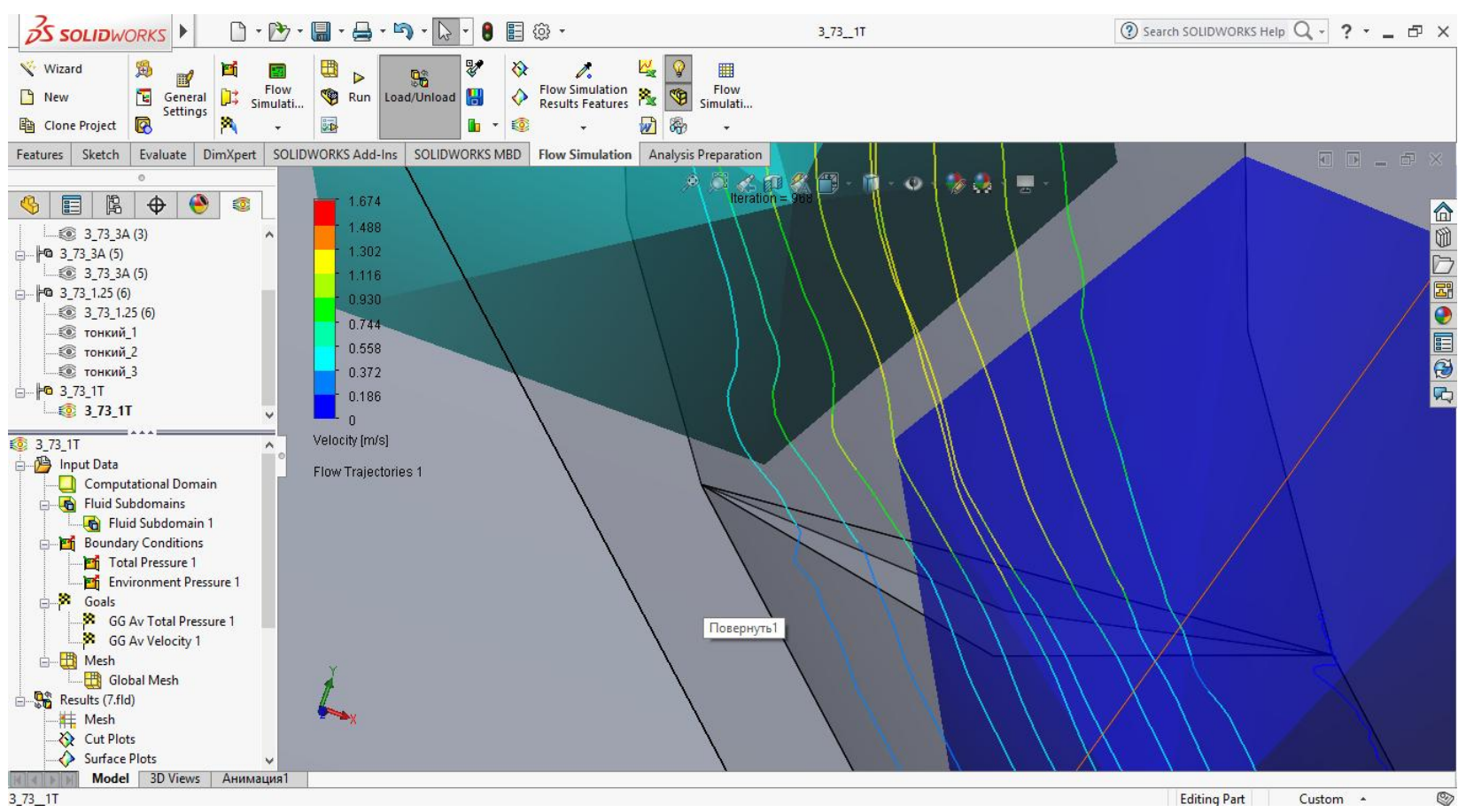

Fig. 7. Diagram of flow rates of drilling mud in the exit of the spiral gap channel 


\section{Conclusions}

1. Reducing the height cross section of the spiral gap between the pin and the box from $0.5 \mathrm{~mm}$ to $0.134 \mathrm{~mm}$ and the width of its base from $1,6 \mathrm{~mm}$ to $1 \mathrm{~mm}$ leads to a decrease in the speed of movement of the mud in it of 40-50 times.

2. The distribution of the mud rate along the cross section of the reduced channel shows almost zero value at its peripheral parts and the maximum in the middle - the value reaches $1.1-1.3 \mathrm{~m} / \mathrm{s}$.

3. The distribution of the speed of the drilling mud along the exit and entrance section of the newly formed screw channel is the same.

4. Consequently, the reduction of hydraulic costs and wear of the tool-joint tapered thread of the drill string can be achieved by changing the cutting part of the cut tools.

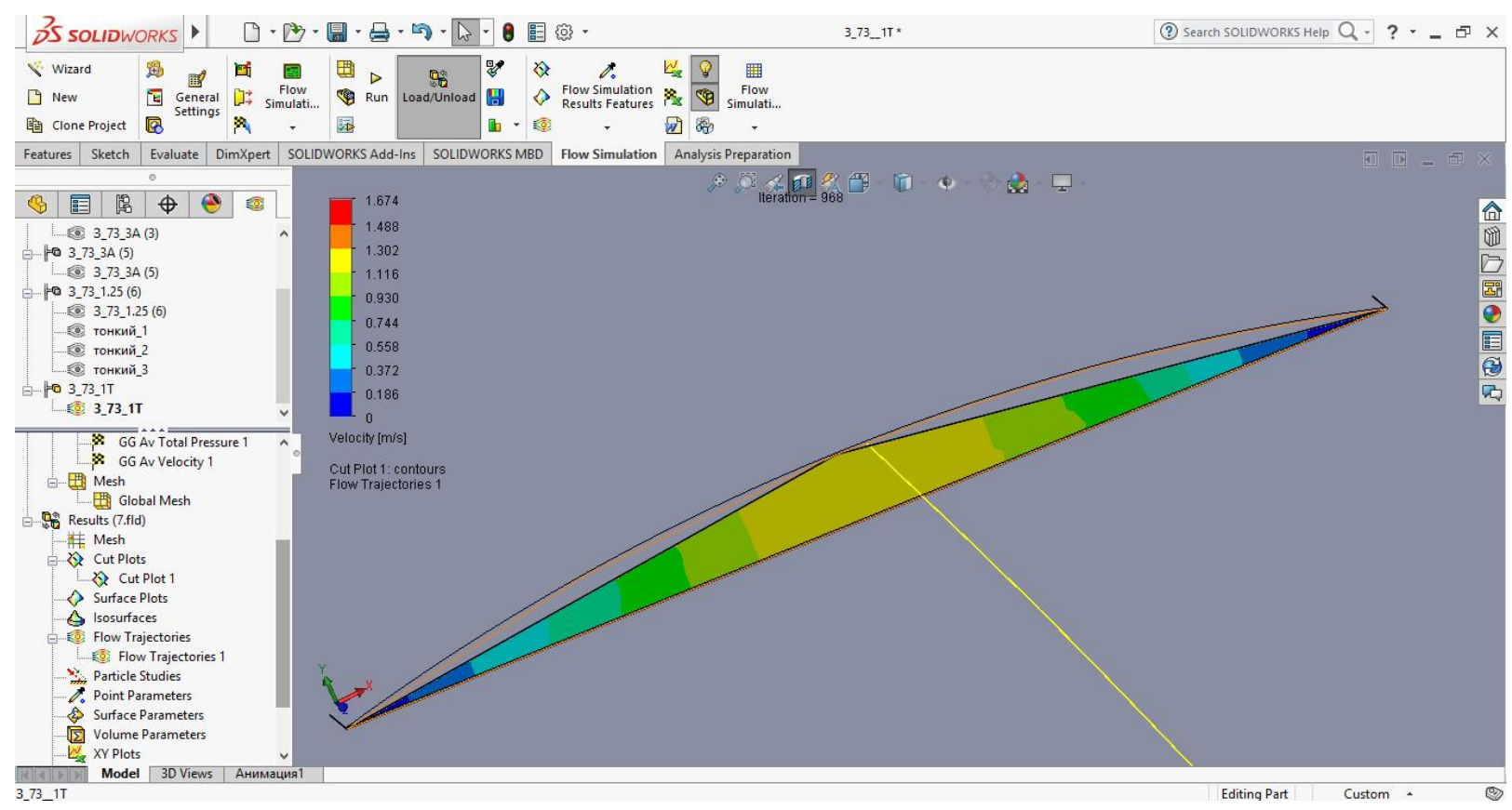

Fig. 8. Diagram of flow middle speed of drilling mud in the entrance of the spiral gap channel

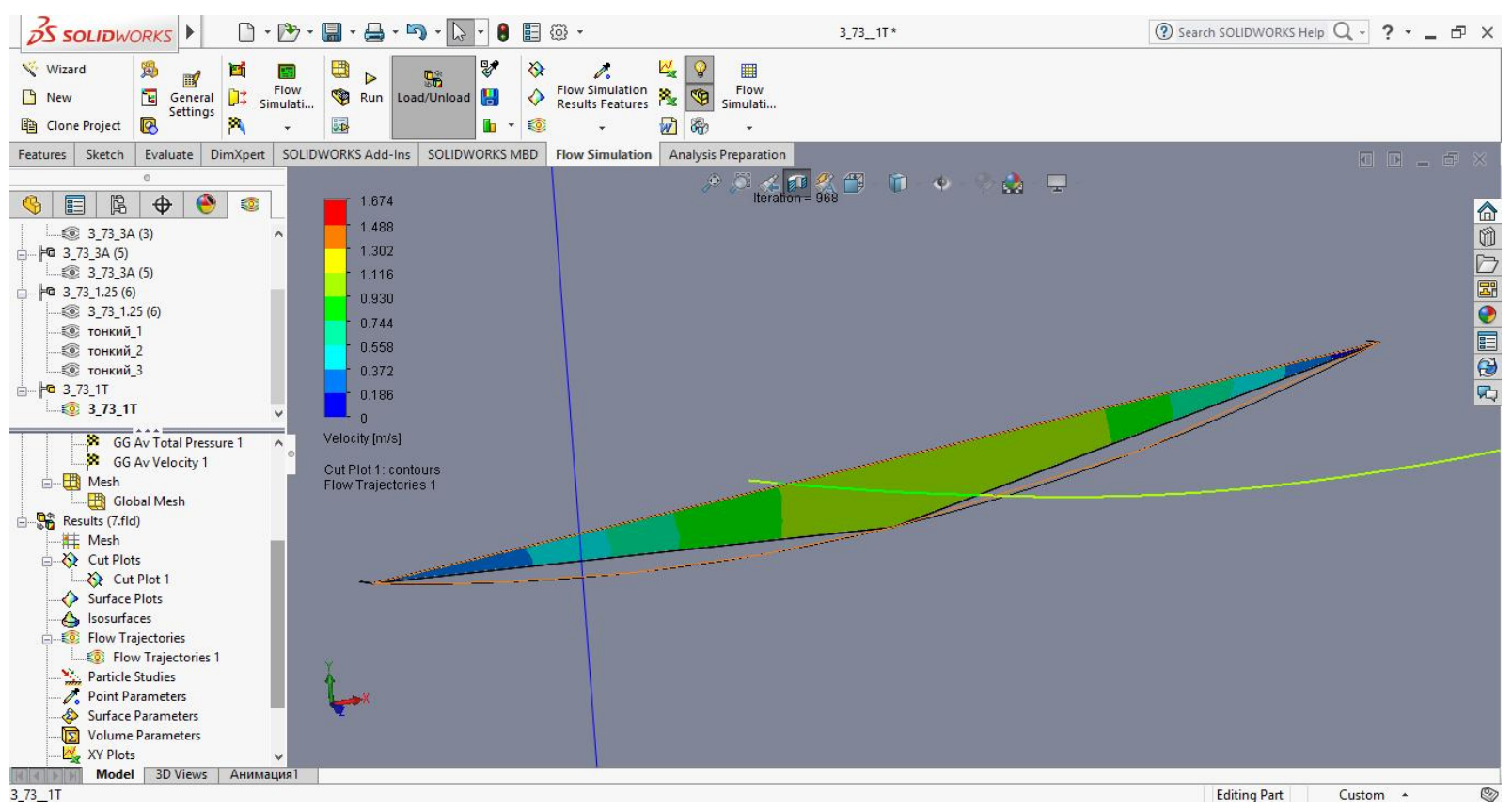

Fig. 9. Diagram of flow middle speed of drilling mud in the exit of the spiral gap channel 


\section{References}

[1] Ju. M. Gerzhberg et al., "Preduprezhdenie razgermetizacii zamkovyh rez'bovyh soedinenij bjuuril'noj kolonny pri rotornom burenii v iskrivlennom stvole skvazhiny" ["Prevention of depressurization of threaded tool joint of the drill string during rotor drilling in the deviated hole"], Izvestija Komi NC UrO RAN [Proceedings of the Komi Science Centre of the Ural Division of the Russian Academy of Sciences], vol. 1 (13), pp. 74-78, 2013. (in Russian).

[2] Rez'ba konicheskaja zamkovaja dlja jelementov buril'nyh kolonn. Profil'. Razmery. Dopuski [Conical lock thread for elements of drill columns. Profile. Dimensions. Tolerances], GOST Standard 28487-90, 2010. (in Russian).

[3] N. D. Shcherbjuk, "Issledovanie i razrabotka konstrukcij rez'bovyh soedinenij trub neftjanogo sortamenta i zabojnyh dvigatelej s vysokimi jekspluatacionnymi harakteristikami dlja burenija glubokih skvazhin" ["Research and development of threaded joints of oil-grade pipes and downhole motors with high performance characteristics for drilling deep wells"], Doctoral dissertation, Vsesojuznyj nauchno issledovatel'skij institut burovoj tehniki Minnefteproma SSSR [All-Union Scientific Research Institute of Drilling Equipment of the USSR Minnefteprom], Moscow, Russia, 1978. (in Russian).

[4] A. I. Baryshnikov, "Rabotosposobnost' rez'bovyh soedinenij buril'noj kolonny pri ciklicheskom nagruzhenii" ["Working capacity of threaded joints of the drill string under cyclic loading"], Ph.D. dissertation, Vsesojuznyj nauchno issledovatel'skij institut burovoj tehniki Minnefteproma SSSR [All-Union Scientific Research Institute of Drilling Equipment of the USSR Minnefteprom], Moscow, Russia, 1984. (in Russian).

[5] B. Ju. Shcherbakov, "Novaja vysokotehnologichnaja produkcija ZAO "TMK" dlja stroitel'stva neftjanyh i gazovyh skvazhin v sovremennyh uslovijah" ["New high-tech products of CJSC TMK for construction of oil and gas wells in modern conditions"], Vestnik Associacii Burovyh Podrjadchikov [Bulletin of the Association of Drilling Contractors], no. 1, pp. 37-42, 2005. (in Russian).

[6] I. I. Chudyk, "Do vtrat hidravlichnoi enerhii pid chas promyvannia sverdlovyny" ["About losses of hydraulic energy during well washing"], Rozvidka ta rozrobka naftovykh i hazovykh rodovyshch [Prospecting and Development of Oil and Gas Fields], vol. 2 (31), pp. 34-42, 2009. (in Ukrainian).

[7] L. Borushchak, O. Onysko and V. Panchuk, "Research of the impermeability of the tool-joint tapered thread size $27 / 8$ reg," in Problemy eksploatacji i zarzqdzania w górnictwie [Problems of operation and management in mining industry], Krzysztof Kotwica, Ed. Kraków, Poland: Zakład Poligraficzny A. Kozień Publ., 2017, pp. 65-72.

[8] H. B. Krykh, "Osoblyvosti zastosuvannia reolohichnykh modelei neniutonivskykh ridyn" ["The influence of the working medium on the kinematics of vibration machines"], Visnyk natsionalnoho universytetu "Lvivska politekhnika". Seriia "Teploenerhetyka. Inzheneriia dovkillia. Avtomatyzatsiia" [Bulletin of Lviv Polytechnic National University. Series "Heat Power Engineering. Environmental Engineering. Automation"], no. 581, pp. 71-82, 2007. (in Ukrainian).

[9] I. I. Chudyk, V. V. Bohoslavets, I. F. Dudych, "Biopolimer-sylikatnyi burovyi rozchyn dlia burinnia horyzontalnykh sverdlovyn" ["Biopolymer-silicate drilling mud for drilling horizontal wells"], Rozvidka ta rozrobka naftovykh $i$ hazovykh rodovyshch [Prospecting and Development of Oil and Gas Fields], vol. 4 (61), pp. 34-42, 2016. (in Ukrainian). 